\title{
The need to integrate Public Health courses in Health Professions curriculum
}

\author{
*Arjun Dutta \\ Senior Associate Dean \& Professor, Marshall B. Ketchum University, USA
}

Submission: May 11, 2017; Published: May 23, 2017

*Corresponding author: Arjun Dutta, Senior Associate Dean \& Professor College of Pharmacy, Marshall B Ketchum University, 2575 Yorba Linda Blvd, Fullerton, California 92831, USA, Tel: 714-872-5693; Fax: 714- 872-5706; Email: ADutta@ketchum.edu

\section{Letter to Editor}

Healthcare delivery is moving towards a more integrated and interprofessional approach. Health professionals, including pharmacists will need to work as part of a team to deliver optimal care to patients. As such, it is imperative that health professionals are trained in the aspect of interprofessional education. One of the aspects of interprofessional education is advocacy for public health principles. Without a proper understanding of public health concepts, it is difficult for health professionals to deliver the care necessary for the patient's long term well-being. This begs the question, how much of public health is being taught in current medical, dental, nursing, and pharmacy curriculum?
While a cursory glance at available health professions curriculum reveals that public health courses and principles are part of the coursework, it is yet to be considered relevant or important as the core courses. The public health courses are in fact the conduit by which different health professionals can be educated on a common platform. These courses form the glue that provides interprofessional education opportunities to health professionals.

There should be a conscious effort made by the different health disciplines to integrate more public health concepts and principles into their curriculum and use it as an opportunity to provide interprofessional education.

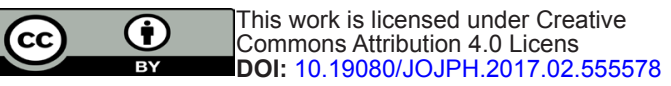

Your next submission with Juniper Publishers will reach you the below assets

- Quality Editorial service

- Swift Peer Review

- Reprints availability

- E-prints Service

- Manuscript Podcast for convenient understanding

- Global attainment for your research

- Manuscript accessibility in different formats

( Pdf, E-pub, Full Text, Audio)

- Unceasing customer service

Track the below URL for one-step submission https://juniperpublishers.com/online-submission.php 